\title{
Articulatory Information for Spelling Strategies
}

\author{
Bobae Kim, Minwha Yang \\ Department of Education, Kookmin University, Seoul, Korea
}

\author{
Correspondence: Minwha Yang, PhD \\ Department of Education, Kookmin University, \\ 77 Jeongneung-ro, Seongbuk-gu, Seoul 02707 , \\ Korea \\ Tel: +82-2-910-4862 \\ Fax: +82-2-910-4359 \\ E-mail: myang@kookmin.ac.kr
}

Received: July 2, 2015

Revised: August 14, 2015

Accepted: August 25, 2015

\begin{abstract}
Objectives: This study aimed to find differences in spelling strategies between students with and without spelling difficulties by identifying differences in the orthographic logic of the two groups. Methods: Two hundred seventy-six elementary students in grade 1 and 2 were administered a spelling test. A series of chi-square tests were conducted to identify relationships between the spelling difficulties and the spelling error patterns in terms of the manner and the place of articulation of target features. The Mann-Whiteney $U$ nonparametric test was applied to identify spelling error patterns within the groups. Results: First, there was a significant correlation between group membership and spelling error patterns in terms of the manner of articulation. Students without spelling difficulties made more substitution errors to letters sharing the same manner of articulation than letters not sharing the manner of articulation. There was no such substitutional pattern found among students with spelling difficulties in terms of the manner of articulation. Second, a correlation was found between group membership and the spelling error patterns in terms of the place of articulation when spelling final consonants. Both groups made more substitution errors with different places of articulation. Conclusion: Students without spelling difficulties applied spelling strategies related to the manner of articulation of target features. Spelling strategies regarding the place of articulation of phonemes were found in neither of the groups. These results display that there is a difference in the orthographic logic behind the spelling strategies between students with and without spelling difficulties.
\end{abstract}

Keywords: Spelling strategies, Spelling difficulties, Manner of articulation, Place of articulation

철자란 자음과 모음을 맞추어 음절 단위의 글자를 만드는 것으 로, 글을 쓰고 학습하는 데 기초적인 작업이라고 할 수 있다. 한글 맞춤법은 '표준어를 소리대로 적되, 어법에 맞도록 함으로써 원칙 을 삼는다.라고 제시되어 있다. 따라서 한글에서의 올바른 철자를 위해서는 기본적으로 소리나는 대로 철자를 하되, 어법 규칙이 적 용되는 경우 그에 맞게 철자를 해야한다. 그렇다면 철자에서 나타 나는 오류는 소리나는 대로 적는 과정에서 나타나는 오류일 수도 있고 어법 규칙에 어긋나는 오류일 수도 있다.

아동의 철자오류 분석을 처음으로 시도한 학자는 Read이다. Read (1971)는 학령기 이전의 아동들이 이미 언어의 소리체계에 대해 인 식하고 있으며, 나름의 논리를 가지고 있다고 주장하면서 그 증거 로 아동의 철자오류를 들었다. 글자소리에 대한 완전한 이해가 이 루어지지 않은 아동들의 철자오류라 하더라도 그 오류가 무작위적 인 것이 아니라 글자이름이나 조음위치를 활용하여 대체한 오류라
는 것이다. 아동은 글을 읽고 철자할 때 자신이 가지고 있는 글자체 계에 대한 논리를 전략으로 이용한다. 그렇기 때문에 철자에서 나 타난 오류를 분석한다면 아동들이 언어의 소리체계를 어떻게 이해 하고 있는지 알아볼 수 있다.

Read의 철자발달 연구를 지속하여 이론화시킨 학자는 Henderson이다. Henderson (1990)의 철자발달이론에 따르면, 영어권 아 동은 발달 초기에 소리 나는 대로 쓰는 음운적인 유형들을 배우고 (예: 단어 'hat'의 첫 자음소리 h), 그 후에는 일정한 덩이로 철자되 는 패턴유형들을 배운다(예: 덩이로 출현하는 str, or, igh 등의 패 턴). 마지막으로 의미를 나타내는 형태소는 소리가 바뀌어도 변하 지 않고 철자됨을 인식하여 형태소유형들을 정확히 철자하는 단계 까지 발달한다(예: signal에서 n은 소리가 나지 않지만, sign이라는 어근을 밝히기 위해 철자함).

한글철자발달을 연구한 이전 연구에서 Yang (2014)은 요인분석 
을 통해 한국어 철자유형들이 음운유형과 형태소유형으로 크게 나누어지며 패턴유형군은 없다고 밝혔다. 또한 음운유형들은 대부 분 1학년 때 이미 학습이 완성되고, 기본종성 등 어려운 음운유형 은 3학년에서 완성되며, 형태소유형들은 대부분 3 학년까지도 완전 한 습득이 이루어지지 않는 것으로 나타났다. 또한 아동의 초기 발 달을 보고자 만 5 세 일반아동을 대상으로 1 년 동안 4 번에 걸쳐 추 적 조사한 결과 자소-음소 대응이 명백한 기본초성, 기본종성, 기 본모음의 음운학적 유형들을 먼저 학습하고 어려운 음운변동 유형 이나 7종성패턴유형 등은 나중에 습득한다는 것이 발견되었다

(Yang, 2009).

따라서 Henderson이 제시한 철자발달이론과 한글의 철자발달 은 세부적으로는 차이가 있지만 큰 틀에서는 동일한 패턴으로 발 달이 이루어지고 있는 것을 알 수 있다. 한글의 경우 유치원과 초등 학교 저학년 시기에 음운적 지식만을 요구하는 단어들에 대한 철 자는 어느정도 완성이 되지만, 형태소적 지식이 필요한 단어들을 철자하는 것에는 어려움을 느낀다. 즉, 초등학교 저학년 아동들은 철자를 하는 데 있어서 음운학적 전략을 잘 활용하고 있으나 형태 소적 전략을 활용하는 데는 어려움이 있다는 것이다.

아동의 철자전략을 분석하는 것은 철자교수와 진단에 필요한 시 사점을 제공할 수 있기 때문에 매우 중요하다고 할 수 있다(Beers, Beers, \& Grant, 1977; Henderson, 1990). 전략(strategy)은 기술(skill) 이나 능력(ability)과 혼용되고 있으나 명확히 차별되는 개념이다. 전 략이란 의도적이고 목표지향적으로 통제된 시도로서 아동이 노력 하고 있는 인지수행이다. 반면, 기술은 의도가 개입되지 않은 자동 화된 수행을 말한다(Afflerbach, Pearson, \& Paris, 2008). 기술과 전 략의 가장 큰 차이점은 자동화와 의도된 통제의 유무에 있다. 예를 들어 음운적 정보, 그중에서도 조음방법에 대한 정보를 의도적으로 분석하여 철자에 이용한다면 이것은 철자전략이 된다. 그러나 오랜 훈련 끝에 조음방법에 대한 정보를 별다른 노력 없이 자동적으로 분석하여 음운적으로 정확한 철자를 하게 된다면 이것은 음운적 철자기술이 습득된 것이다. 따라서 아동이 철자기술을 습득하도록 돕기 위해서는 아동이 활용하는 철자전략을 분석하여 이들이 사용 하는 전략의 효율성을 파악하고, 기술습득을 위해 효율적인 철자 전략을 체계적이고 집중적으로 가르쳐 줄 필요가 있다.

이전의 몇몇 연구들은 철자전략 활용에서 일반아동과 철자부진 아동 사이에 차이가 있음을 보고해왔다. Weiner (1994)는 철자부 진아동 2 명과 일반아동 2 명이 보인 철자오류의 분석과 함께 인터뷰 를 진행하였다. 이를 바탕으로 두 그룹의 아동이 철자에 사용한 철 자전략을 비교한 결과 두 그룹 사이에 사용하는 철자전략에는 차 이가 있었다. 철자부진아동들은 소리와 상징을 대응시키는 음운학
적 전략에 주로 의존하는 반면, 일반아동들은 패턴전략과 의미전 략도 사용한다는 것이다. 우리나라에서도 쓰기장애아동이 정상아 동에 비해 음운적 오류와 띄어쓰기오류를 더 많이 보인다고 보고 된 바 있다(Shin \& Cho, 2001). 또한 Kim, Choi와 Kim (2010)은 초 등학교 철자부진아동이 일반아동에 비해 규칙단어 정확도와음운 변동단어 정확도가 모두 낮음을 밝혔다. 그러나 이러한 보고들은 일반아동과 철자부진아동의 철자기술에 차이가 있음을 밝혔지만 철자전략을 비교하지는 못하였다는 점에서 한계가 있다. 본 연구에 서는 철자부진아동과 일반아동의 철자전략을 비교하여 아동이 어 떠한 전략을 이용하며, 두 그룹 간 전략의 차이가 있는지 확인해보 고자 한다.

또한 현재 철자교수는 학령기 초기에 집중적으로 이루어지고 있 다. 따라서 학령기 초기 아동들이 가장 많이 사용하는 음운학적 철 자전략을 분석하여 아동의 철자전략을 밝히는 것이 중요하다고 할 수 있다. 음운학적 철자전략에 필요한 철자기술에는 음소인식능력 과 글자지식이 있으며(Ehri, 2000), 그 중 음소인식 발달은 음소의 조음측면의 요소에 영향을 받는다(Anthony \& Francis, 2005). 음 소의 성질을 규정하는 요소로는 조음방법, 조음위치, 성대울림의 유무 등이 있는데, 조음방법은 조음 시 장애를 받는 방식을 의미하 며, 조음위치는 조음 시 장애를 받는 자리를 의미한다(Lee, 2011). 선행연구들에서 난독증 성인들이 어느 정도 읽기문제가 해소된 후 에도 여전히 조음위치에 대한 지각능력이 일반성인에 비해 현저하 게 낮다는 보고가 있었으며(Griffiths \& Frith, 2002), 유아기 조음의 질이 학령초기 음소인식 능력을 예측한다는 연구도 있었다(Thomas \& Sénéchal, 2004). 또한 음소인식능력의 발달이 음소의 조음방 법이나(Treiman, 1984) 조음위치에 영향을 받는다는 연구도 있었 다(Treiman, Broderick, Tincoff, \& Rodriguez, 1998). 이러한 연구들 은 음소정보를 주로 사용하는 초기철자발달 시기 아동들이 조음위 치와조음방법을 철자전략으로 사용할 가능성이 높음을 시사한다.

자음은 조음방법과 조음위치를 기준으로 분류되며, 모음은 혀 의 위치나 입술의 모양에 따라 결정되는 특징을 가진다. 모음은 자 음과 달리 정확히 어떤 조음방법이나 조음위치의 작용으로 발음 되는지 기술하기 어려운 특징이 있다(Lee, 2011). 따라서 본 연구는 자음의 조음방법과 조음위치의 측면에서 아동들이 사용하는 철 자전략을 우선 밝히고자 한다.

조음 측면의 연구는 주로 조음발달 연구에서 진행되어 왔다(Kim, 1996; Treiman, 1984). 영어권에서는 유음, 비음, 전이음, 폐쇄음 순 으로 음소인식 발달이 이루어진다고 보고되었으며(Treiman, 1984), 국내에서는 일반아동의 개별음소의 점수를 조음위치, 조음방법, 발성방법 등 조음의 특성에 따라 분석하여 그 발달 패턴을 연구한 
한 차이가 있는가?

바 있다(Kim, 1996). Kim (1996)은 95\%-100\%의 아동이 바르게 조 음한 단계를 완전습득연령 단계로 보고, 이 완전습득 단계에 도달 한 개별음소의 순서를 조음 특성별로 분석한 결과, 조음위치 측면 에서는 양순음, 치조음, 연구개음, 성문음, 경구개음의 순으로 습득 되었다. 또, 조음방법 측면에서는 비음 및 파열음이 먼저 습득되고 파찰음, 마찰음, 유음은 비슷한 수준으로 습득되었다. 이러한 결과 는 조음의 특성에 따라 발달의 패턴이 다름을 보여준다.

또한 $\operatorname{Kim}(1996)$ 은 개별음소의 정확도도 함께 분석하였는데 같 은 조음위치 혹은 조음방법이라고 하더라도 개별 음소에 따라 자 음정확도는 상이하였다(예: 2 세 남아 /니초성 정확도는 $95 \%$, / ㅅ/ 초성 정확도는 $36 \%$ 로 같은 치조음이지만 음소에 따라 차이가 있 음). Kim의 연구는 각 조음의 특성에 따라 조음발달의 패턴을 분석 했을 뿐만 아니라 음소별로 발달 패턴을 밝혔다는 점에서 의의가 있다고 할 수 있다. 조음발달은 음소인식의 발달과 매우 밀접한 관 계가 있기 때문에(Rvachew, Ohberg, Grawburg, \& Heyding, 2003), 이와 같은 조음발달의 순서는 초기읽기교수와 장애학생들을 위한 음소인식교수의 순서를 정하는 데 활용될 수 있다. 그러나 음소인 식 교수는 단어읽기와 철자하기 등 파닉스 교수와 연합하여 교수 되는 것이 일반적인데(National Reading Panel, 2000), 체계적인 교 수순서를 제안하기 위하여 조음발달의 순서가 철자발달의 순서와 동일한지, 또는 그렇지 않은지에 대한 확인이 필요하다.

따라서 학령 초기에 음운학적 철자발달이 이루어지고 있으며, 일반아동과 철자부진아동 간에 철자전략에 질적인 차이가 있다는 이전 연구결과를 바탕으로(Weiner, 1994; Yang, 2009, 2014), 조음 방법과 조음위치를 두드러진 특징으로 하는 초성과 종성자음의 철자오류를 분석하고자 한다. 초등학교 1,2 학년 일반아동과 철자 부진아동을 대상으로, 이들의 자음철자 오류에 질적 차이가 자음 의 조음방법과 조음위치에 따라 존재하는지, 그리고 철자오류의 논리에 차이가 있는지에 대해 알아보고자 한다. 연구 문제는 다음 과같다.

1) 일반아동과 철자부진아동의 초성자음 대체오류 양상에 유의

2) 일반아동과 철자부진아동의 종성자음 대체오류 양상에 유의 한 차이가 있는가?

\section{연구방법}

\section{연구대상}

서울, 경기도, 전라도, 경상도 지역 내에 위치한 4 개의 초등학교 1,2 학년 학생들이 이 연구에 참여하였다. 참여 학생은 총 276명이 었으며, 이 중 남학생은 141 명, 여학생은 135 명이었다. 지역별로 살 펴보면 서울 지역의 학생은 77 명, 경기도 지역의 학생은 134 명, 전라 도 지역의 학생은 46 명, 그리고 경상도 지역의 학생은 19 명이었다. 철자검사 결과 유형점수와(목표한 철자유형이 정확하게 철자되었 을 때 부여하는 점수) 정확점수를(단어가 정확하게 철자되었을 때 부여하는 점수) 합산한 총점을 기준으로 하위 $25 \%$ 아동들을 철자 부진아동으로 선정하였으며, 상위 $75 \%$ 의 학생들을 일반아동으로 분류하였다(Lennox \& Siegel, 1996). 분류 결과 일반아동은 205명, 철자부진아동은 71명이었다. 연구대상의 인구학적 특징은 Table 1 에 제시되어 있다.

\section{검사도구}

연구를 위하여 초성자음과 종성자음 철자능력을 검사할 수 있 는 철자검사도구를 개발하였으며, 총 14 개의 단어로 이루어졌다 (Appendix 1). 초성자음만을 검사하는 단어는 5개, 종성자음만을 검사하는 단어는 2 개, 초성자음과 종성자음을 동시에 검사하는 단 어는 7 개로 구성되었다. 이는 연구대상이 초등학교 1,2 학년 아동 들임을 감안하여 한 번에 실시하기 적합한 문항의 수로 조정하기 위함이었다.

초성자음은 거센소리와 된소리초성의 철자가 평음초성 철자와 는 다른 패턴으로 학습된다는 이전연구를 바탕으로(Yang, 2009), 가장 기초가 되는 평음초성 자소 'ㄱ, ㄴ, ᄃ, ㄹ, ㅁ, ㅂ, ㅅ, 즈만을

Table 1. Demographic information of participants

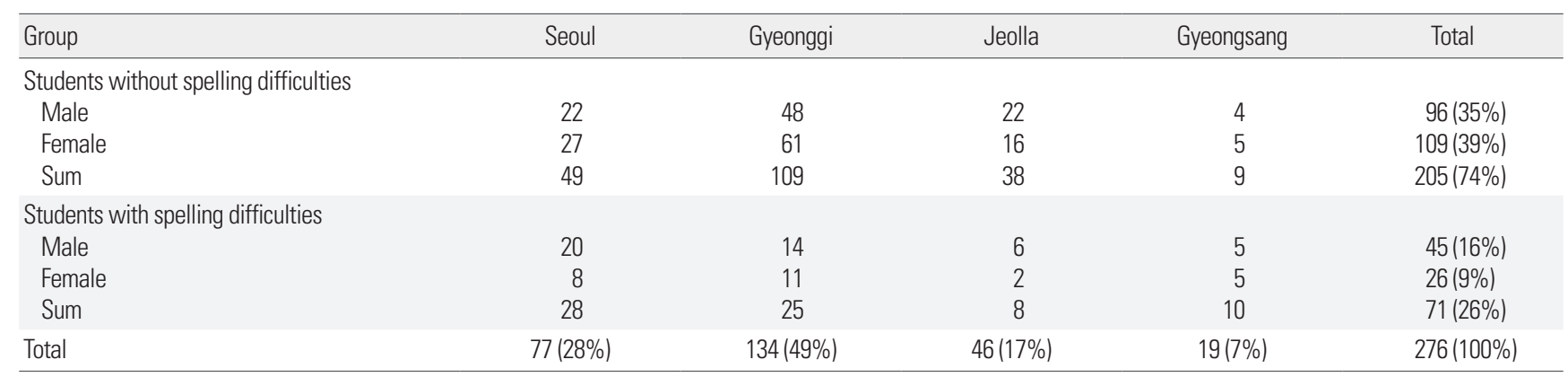


포함하였다. 종성에는 'ㄱ, ᄂ, ᄃ, ᄅ, ㅁ, ㅂ, ㅇㅇㅣ 포함되었으며

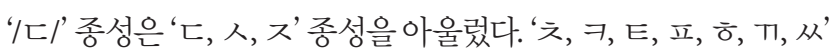
종성은 목표초성에 포함되지 않았으므로 검사에서도 제외하였다.

검사 단어는 어휘의 수준을 나누어 등급별로 정리한 책인 "등급 별 국어 교육용 어휘(Kim, 2003)"에서 추출하였다. 1 등급 어휘는 기초어휘이고, 2 등급 어휘는 정규교육 이전의 어휘, 3 등급 어휘는 정규교육 개시 이후의 어휘이다. 검사 단어는 $1,2,3$ 등급의 어휘에 서 단어를 추출하였다.

\section{검사실시 및 채점}

본 연구의 검사는 학급 담임교사가 검사를 진행한 후, 검사지를 회수하는 방식으로 실시되었다. 검사실시 전 연구자는 담임교사에 게 검사 목적, 검사의 구성, 검사방법과 유의점 대한 구체적인 설명 을 제공하였고, 담임교사는 이에 대한 내용을 아동들에게 설명한 후 검사를 실시하였다. 검사는 모두 집단검사로 실시되었으며, 담임 교사가 아동들에게 검사 단어를 불러주고, 단어가 포함된 문장을 불러준 다음, 마지막으로 단어를 한 번 더 불러주는 방식으로 진행 되었다. 아동은 미리 나누어준 검사지에 이름을 작성하고 불러주 는 단어만을 해당 번호 칸에 철자하도록 지도되었으며, 시작하기 전에 연습문제를 실시하여 학생들로 하여금 검사방식에 대한 이해 정도를 확인하고 검사를 진행하였다. 검사 중 학생의 요청이 있을 시에는 한 번 더 단어를 불러주었다. 검사시간은 5 분에서 10 분 정 도가소요되었다.

채점은 연구자와 도구 개발에 참여하였던 대학원생이 실시하였 다. 채점방법은 각 단어의 목표철자유형이 정확하게 철자되어 있으 면 1점, 그렇지 못한 경우 0점의 유형점수를 받도록 채점하였다(예: 초성자음 'L'을 목표한 단어 '능선'의 경우 ‘능전'이라고 썼을 경우 유형점수 1 점을 주었고, ‘등선’이라고 썼을 경우 유형점수 0 점을 부 여함). 단, 종성자음에서 같은 소리로 조음되는 다른 자소로 대체 한 경우에는 음운학적으로 맞는 응답이므로 정답으로 인정하였다 (예: 종성자음 'ㅂ'을 목표한 단어 '조립'의 경우 /비로 조음되는 자 소인 ‘ㅂ'과 ‘표' 모두 정답으로 처리하여 ‘조맆과 ‘조립’ 모두 유형점 수 1점을 부여함). 이는 이전 연구의 채점기준을 참고한 것이다 (Kim, 2010; Yang, 2014). 또한 정확하게 단어가 철자되었을 경우에 정확단어점수 1 점을 추가로 부여하였다. 예를 들어 '능선'의 경우 ‘능선'이라고 철자하였을 경우 유형점수 1 점에 정확점수 1 점을 부 과하여 2점을 주었으며, 초성자음 'ㄴ을 정확하게 철자한 '능전'은 유형점수 1 점만을, 유형을 정확히 철자하지 못한 등선'은 0 점 처리 하였다. 유형점수와 정확점수를 합한 총점은 아동의 철자수행도를 파악하여 철자부진아동과 일반아동을 분류하는 데 사용된 점수
이며, 결과 분석에서 제시된 자소별 정확도는 오직 유형점수만을 사용하여 산출하였다.

\section{결과 분석방법}

철자부진 유무와 초성자음과 종성자음을 철자하는 데 있어서 조음방법과 조음위치의 측면에서 대체오류의 양상과의 상관관계 가 있는지 알아보기 위해 카이제곱 검정(chi-squrae test)을 실시하 였다. 또한 카이검정 결과 상관관계가 유의한 경우, 만-휘트니 $U$ 비 모수 통계검증(Mann-Whitney $U$ test)을 통해 철자부진아동과 일 반아동이 집단 내에서 보이는 대체오류의 유형의 차이가 나타나는 지 알아보았다.

\section{연구 결과}

개별 자소의 정확도는 자소가 초성에 위치해 있는지 종성에 위 치해 있는지에 따라 차이가 발견되었다(Table 2). 종성에 위치한 경 우의 정확도가 초성에 위치한 경우의 정확도보다 전반적으로 낮았 으며, 일반아동보다 철자부진아동 사이에서 그 차이가 보다 명확 하게 나타났다. 예를 들어 자음 'ㅂㅇㅢ 경우 초성에서의 정확도는 $97.83 \%$ 였으나 종성에 위치했을 때의 철자정확도는 $81.16 \%$ 였다. 철 자부진아동만 보았을 때는 그 차이가 보다 명확하여 초성에서의 철자정확도가 $95.07 \%$, 종성에서의 철자정확도가 $56.34 \%$ 였다.

초성의 경우 'ㅅ, 질, ㅁㄴ ㄴ, ᄃ, ㅂ> ᄀ' 순으로 정확도가 높 았고, 종성은 'ㄹ> ᄂ > ㄱ> ㄱ> O > ㅂ > ᄃ' 순으로 정확도가 높 았다. 철자부진아동과 일반아동 사이에 자소의 정확도에 따른 순 서는 큰 차이가 없었다.

개별 자소별로 초성과 종성에 위치할 경우의 정확도 차이는 상 이하였다. 자소 'ㄱ, ᄂ, ᄅ’은 비교적 초성에서의 정확도와 종성에 서의 정확도 간에 차이가 크게 나타나지 않았으나, 자소 ‘ㄷ, 버의 경우 자음 위치에 따른 자소 정확도의 차이가 두드러졌다. 특히 자 소'ㅅ, 즈은 초성자음에 위치하였을 때 철자부진아동들 사이에서 도 개별 자소들 중 가장 높은 정확도를 보였으나, 종성에서/디로 발음될 때는(동일하게 /ㄷ/로 발음되는 'ㄷ, ㅅ, 조' 자소는 모두 종 성자음에서 종성 'ㄷ으로 처리하여, 종성 /디 총 정확도는 78.8\% 로 타나남) 종성자음의 자소 중 가장 낮은 정확도를 보였다.

\section{일반아동과 철자부진아동의 초성자음 대체오류 비교} 조음방법

초성자음의 조음방법 측면에서 나타난 철자 정확도는 Table 3에 제시된 바와 같다. 전체아동의 조음방법별 철자 정확도는 마찰음 
Bobaekim, etal. Articulatory lnformation for Spelling Strategies

Table 2. Spelling accuracy (\%) by consonants

\begin{tabular}{|c|c|c|c|c|c|c|}
\hline \multirow[b]{2}{*}{ Grapheme } & \multicolumn{3}{|c|}{ Initial consonants } & \multicolumn{3}{|c|}{ Final consonants } \\
\hline & $\begin{array}{l}\text { Students with } \\
\text { spelling difficulties }\end{array}$ & $\begin{array}{l}\text { Students without } \\
\text { spelling difficulties }\end{array}$ & Total & $\begin{array}{c}\text { Students with } \\
\text { spelling difficulties }\end{array}$ & $\begin{array}{l}\text { Students without } \\
\text { spelling difficulties }\end{array}$ & Total \\
\hline$\urcorner$ & 89.44 & 94.39 & 93.12 & 81.69 & 96.59 & 92.75 \\
\hline ᄂ & 95.07 & 98.78 & 97.83 & 86.62 & 98.29 & 95.29 \\
\hline ᄅ & 96.48 & 98.78 & 98.19 & 90.85 & 99.51 & 97.28 \\
\hline 口 & 95.07 & 99.76 & 98.55 & 88.03 & 96.59 & 94.38 \\
\hline$\forall$ & 95.07 & 98.78 & 97.83 & 56.34 & 89.76 & 81.16 \\
\hline ᄃ & 94.37 & 99.02 & 97.83 & 59.86 & 85.37 & 78.8 \\
\hline ᄉ & 97.89 & 100 & 99.46 & & & \\
\hline x & 97.89 & 99.51 & 99.09 & & & \\
\hline$\circ$ & - & - & - & 71.83 & 94.15 & 88.41 \\
\hline Total & 95.16 & 98.63 & 97.74 & 76.46 & 94.32 & 89.73 \\
\hline
\end{tabular}

Table 3. Spelling accuracy (\%) by the manner of articulation of initial consonants

\begin{tabular}{|c|c|c|c|c|c|c|c|}
\hline $\begin{array}{l}\text { Manner of articulation } \\
\text { Plosive }\end{array}$ & \multirow{2}{*}{$\begin{array}{c}\text { Initial consonants } \\
\urcorner \\
\sqsubset \\
\forall\end{array}$} & \multicolumn{2}{|c|}{ Students with spelling difficulties } & \multicolumn{2}{|c|}{ Students without spelling difficulties } & \multicolumn{2}{|c|}{ Total } \\
\hline Plosive & & $\begin{array}{l}89.44 \\
94.37 \\
95.07\end{array}$ & 92.96 & $\begin{array}{l}94.39 \\
99.02 \\
98.78\end{array}$ & 97.4 & $\begin{array}{l}93.12 \\
97.83 \\
97.83\end{array}$ & 96.26 \\
\hline Fricative & ᄉ & 97.89 & 97.89 & 100 & 100 & 99.46 & 99.46 \\
\hline Affricate & x & 97.89 & 97.89 & 99.51 & 99.51 & 99.09 & 99.09 \\
\hline Nasal & $\begin{array}{l}\llcorner \\
\square\end{array}$ & $\begin{array}{l}95.07 \\
95.07\end{array}$ & 95.07 & $\begin{array}{l}98.78 \\
99.76\end{array}$ & 99.27 & $\begin{array}{l}97.83 \\
98.55\end{array}$ & 98.19 \\
\hline Liquid & e & 96.48 & 96.48 & 98.78 & 98.78 & 98.19 & 98.19 \\
\hline
\end{tabular}

Table 4. Substitution errors of initial consonants by the manner of articulation

\begin{tabular}{|c|c|c|c|c|}
\hline & \multicolumn{2}{|c|}{ Substitution types } & \multirow{2}{*}{$\begin{array}{c}\text { Total } \\
\text { substitutions }\end{array}$} & \multirow{2}{*}{$x^{2}$} \\
\hline & Substitution to the different manner of articulation & Substitution to the same manner of articulation & & \\
\hline $\begin{array}{l}\text { Students with spelling } \\
\text { difficulties }\end{array}$ & $28(50.9)$ & $27(49.1)$ & $55(100)$ & $3.982^{*}$ \\
\hline $\begin{array}{l}\text { Students without spelling } \\
\text { difficulties }\end{array}$ & $14(31.1)$ & $31(68.9)$ & $45(100)$ & \\
\hline
\end{tabular}

Values are presented as number (\%).

${ }^{*} p<.05$.

과 파찰음의 정확도가 $99 \%$ 수준에서 비슷했고 그 다음으로 비음 과 유음이 비슷했으며, 파열음이 가장 낮았다. 철자부진아동의 조 음방법별 철자 정확도는 마찰음과 파찰음의 정확도가 $97 \%$ 수준에 서 비슷하였고, 그 다음으로 유음, 비음, 파열음 순으로 나타났으나 그 차이는 크지 않았다. 파열음은 $92 \%$ 의 정확도로 가장 낮게 나타 났다. 일반아동의 조음방법별 철자 정확도는 마찰음의 경우에는 오류가 관찰되지 않아 가장 높은 정확도를 보였으며, 파찰음과 비 음은 $99 \%$ 수준에서 비슷하였고, 그 다음으로 유음과 파열음 순으 로 나타났다. 두 집단의 아동들이 느끼는 조음방법상 자음군에 대 한 난이도 순서는 다르지 않았고, 두 집단 간 가장 큰 정확도의 차 이는 파열음과 비음 자소에서 관찰되었다.
조음방법 측면에서 개별 자소의 철자 정확도를 살펴보면, 파열 음에서 철자부진아동은 ‘ㅂㄷㄷ ㄱ' 순으로 정확도가 높은 것으 로 나타났다. 반면 일반아동은 ‘ㄷ>ㅂ> ᄀᄀ' 순으로 정확도가 높은 것으로 나타났으며, 'ㄱㄱㄱㅘ ‘ㄷ자소에서 철자부진아동과 일반아동 의 정확도의 차이가 특히 두드러졌다. 또한 비음 자소의 정확도에 서도 두 그룹 간 차이가 발견되었으며, 특히 'ㅁ 자소의 경우 일반 아동들은 거의 오류를 보이지 않았다. 일반아동들은 마찰음인 'ㅅ' 에서도 오류가 없었다.

철자부진의 유무와 초성 조음방법 측면의 오류 양상 간에 상관 관계가 있는지 검증한 결과(Table 4), 통계적으로 유의미한 차이를 보였다 $\left(\chi^{2}(1, \mathrm{~N}=100)=3.982, p<.05, \Phi=.05\right)$. 초성자음을 철자할 
Table 5. The frequency ratio of substitution types in spelling initial consonants by the manner of articulation whithin groups

\begin{tabular}{|c|c|c|c|}
\hline & \multicolumn{2}{|c|}{ Substitution types } & \multirow{2}{*}{$z$} \\
\hline & Substitution to the different manner of articulation & Substitution to the same manner of articulation & \\
\hline Students with spelling difficulties & $.39(.75)$ & $.38(.64)$ & -.232 \\
\hline Students without spelling difficulties & $.07(.29)$ & $.15(.37)$ & $-2.889 *$ \\
\hline
\end{tabular}

Values are presented as mean (SD).

${ }^{*} p<.05$.

Table 6. Spelling accuracy (\%) by the place of articulation of initial consonants

\begin{tabular}{|c|c|c|c|c|c|c|c|}
\hline \multirow{2}{*}{$\begin{array}{l}\text { Place of articulation } \\
\text { Bilabial }\end{array}$} & \multirow{2}{*}{$\begin{array}{c}\text { Initial consonants } \\
\square \\
\forall\end{array}$} & \multicolumn{2}{|c|}{ Students with spelling difficulties } & \multicolumn{2}{|c|}{ Students without spelling difficulties } & \multicolumn{2}{|c|}{ Total } \\
\hline & & $\begin{array}{l}95.07 \\
95.07\end{array}$ & 95.07 & $\begin{array}{l}99.76 \\
98.78\end{array}$ & 99.27 & $\begin{array}{l}98.55 \\
97.83\end{array}$ & 98.12 \\
\hline Alveolar & $\begin{array}{l}\llcorner \\
ᄃ \\
\text { ¿ } \\
\text { ᄉ }\end{array}$ & $\begin{array}{l}95.07 \\
94.37 \\
96.48 \\
97.89\end{array}$ & 95.96 & $\begin{array}{l}98.78 \\
99.02 \\
98.78 \\
100\end{array}$ & 99.15 & $\begin{array}{l}97.83 \\
97.83 \\
98.19 \\
99.46\end{array}$ & 98.32 \\
\hline Palatal & x & 97.89 & 97.89 & 99.51 & 99.51 & 99.09 & 99.09 \\
\hline Velar & \urcorner & 89.44 & 89.44 & 94.39 & 94.39 & 93.12 & 93.12 \\
\hline
\end{tabular}

때 오류를 범한 경우, 철자부진아동은 타 조음방법 자소(예: 파열음 '브을 타 조음방법인 비음 'ㅁ' 또는 ''으로 대체)로 대체하는 오류 (50.9\%)와 동일 조음방법 자소(예: 파열음 'ㅂ'을 동일한 조음방법 인 파열음 '뻐, 프, ᄃ, ㄸ, ㅌ, ᄀ, ㄱ, ㅋ으로 대체)로 대체하는 오류 (49.1\%)의 비율이 비슷했다. 반면, 일반아동은 동일 조음방법의 자 소로 대체하는 오류(68.9\%)가 타 조음방법의 자소로 대체하는 오 류(31.1\%)보다 많은 경향성이 있는 것으로 나타났다.

철자부진의 유무와 초성자음 철자 시 보이는 조음방법 대체 유 형 간의 유의한 상관관계를 바탕으로 집단별로 대체오류의 유형 간 차이가 존재하는지 알아보기 위해 만-휘트니 $U$ 비모수 통계검 증을 실시하였다. Table 5에 제시된 바와 같이, 철자부진아동은 타 조음방법 자소로의 대체 빈도와 동일 조음방법 자소로의 대체 빈 도의 차이가 통계적으로 유의미하지 않았다 $(z=-.232, p>.05)$. 반 면 일반아동은 타 조음방법 자소로의 대체 빈도와 동일 조음방법 자소로의 대체 빈도의 차이가 통계적으로 유의미한 것으로 나타났 다 $(z=-2.889, p<.05)$.

\section{조음위치}

초성자음의 조음위치 측면에서 나타난 철자 정확도는 Table 6에 제시된 바와 같다. 전체아동의 조음위치별 철자 정확도는 경구개음 의 정확도가 $99 \%$ 수준으로 가장 높았으며, 그 다음으로 치조음과 양순음이 비슷하였고, 연구개음이 $93 \%$ 수준으로 가장 낮았다. 철 자부진아동의 조음위치별 철자 정확도는 $97 \%$ 수준으로 경구개음 의 정확도 가장 높았고, 그 다음으로 치조음과 양순음이 $95 \%$ 수준
으로 비슷하였으며, 연구개음은 $89 \%$ 의 정확도로 가장 낮게 나타 났다. 일반아동의 조음위치별 철자 정확도는 경구개음과 양순음, 치조음 모두 $99 \%$ 로 비슷하였고, 연구개음은 $94 \%$ 수준의 정확도로 가장 낮게 나타났다. 두 집단이 느끼는 조음위치에 따른 자음군에 대한 난이도 순서는 다르지 않았으며, 두 집단 간 정확도의 차이는 연구개음에서 가장 크게 나타났다.

조음위치 측면에서 개별 자소의 철자 정확도를 살펴보면, 철자 부진아동들이 연구개 ‘ㄱ' 자소의 철자에 특히 어려움을 보인 것을 비롯하여, 양순음과 치조음에 대한 정확도에서도 두 그룹 간에 큰 차이가 나타났다. 특히 철자부진아동들은 치조음 중에서도 'ㄴㄱㅘ ''에서 상대적으로 더 낮은 정확도를 보였으나, 일반아동들은 비 교적 치조음 자소 간에 정확도의 차이를 보이지 않았다.

철자부진의 유무와 초성 조음위치의 측면에서 대체오류 양상과 의 상관관계가 있는지 카이 검증을 실시한 결과(Table 7), 통계적으 로 유의미한 상관관계를 보이지 않았다. 하지만 빈도수를 살펴보 면, 철자부진아동과 일반아동 모두 타 조음위치(예: 양순음 ‘ㅂ'을 타 조음위치인 경구개음 'ㅈ, 쪼 츠으로 대체)로 대체하는 오류가 동일 조음위치(예: 양순음 'ㅂ'을 동일한 조음위치인 양순음 '뻐, 프, ㅁ으로 대체)로 대체하는 오류보다 많은 경향성이 있는 것으로 나 타났다. 철자부진 유무와 조음위치의 측면에서 대체오류 양상은 통계적으로 유의미한 상관관계를 보이지 않았기 때문에 집단별 대 체오류 유형의 차이를 분석하는 만-휘트니 $U$ 비모수 통계검증은 실시하지 않았다. 
(

Table 7. Substitution errors of initial consonants by the place of articulation

\begin{tabular}{|c|c|c|c|c|}
\hline & Substi & ypes & & \\
\hline & $\begin{array}{l}\text { Substitution to the different } \\
\text { place of articulation }\end{array}$ & $\begin{array}{l}\text { Substitution to the same } \\
\text { place of articulation }\end{array}$ & Total substitutions & $\chi^{2}$ \\
\hline Students with spelling difficulties & $39(70.9)$ & $16(29.1)$ & $55(100)$ & 0.607 \\
\hline Students without spelling difficulties & $35(77.8)$ & $10(22.2)$ & $45(100)$ & \\
\hline
\end{tabular}

Values are presented as number (\%).

Table 8. Spelling accuracy (\%) by the manner of articulation of final consonants

\begin{tabular}{|c|c|c|c|c|c|c|c|}
\hline \multirow{2}{*}{$\begin{array}{l}\text { Manner of articulation } \\
\text { Plosive }\end{array}$} & \multirow{2}{*}{$\begin{array}{c}\text { Final consonants } \\
\text { ᄀ } \\
\sqsubset \\
\forall\end{array}$} & \multicolumn{2}{|c|}{ Students with spelling difficulties } & \multicolumn{2}{|c|}{ Students without spelling difficulties } & \multicolumn{2}{|c|}{ Total } \\
\hline & & $\begin{array}{l}81.69 \\
59.86 \\
56.34\end{array}$ & 65.96 & $\begin{array}{l}96.59 \\
85.37 \\
89.76\end{array}$ & 90.57 & $\begin{array}{l}92.75 \\
78.80 \\
81.16\end{array}$ & 84.24 \\
\hline Nasal & $\begin{array}{l}\llcorner \\
\square \\
\circ\end{array}$ & $\begin{array}{l}86.62 \\
88.03 \\
71.83\end{array}$ & 82.16 & $\begin{array}{l}98.29 \\
96.59 \\
94.15\end{array}$ & 96.34 & $\begin{array}{l}95.29 \\
94.38 \\
88.41\end{array}$ & 92.69 \\
\hline Liquid & ᄅ & 90.85 & 90.85 & 99.51 & 99.51 & 97.28 & 97.28 \\
\hline
\end{tabular}

Table 9. Substitution errors of final consonants by the manner of articulation

\begin{tabular}{|c|c|c|c|c|}
\hline & \multicolumn{2}{|c|}{ Substitution types } & \multirow[b]{2}{*}{ Total substitutions } & \multirow[b]{2}{*}{$x^{2}$} \\
\hline & $\begin{array}{l}\text { Substitution to the different manner } \\
\text { of articulation }\end{array}$ & $\begin{array}{l}\text { Substitution to the same manner } \\
\text { of articulation }\end{array}$ & & \\
\hline Students with spelling difficulties & $116(49.6)$ & $118(50.4)$ & $234(100)$ & $23.963^{*}$ \\
\hline Students without spelling difficulties & $41(25.2)$ & $122(74.8)$ & $163(100)$ & \\
\hline
\end{tabular}

Values are presented as number (\%).

${ }^{*} p<.05$.

\section{일반아동과 철자부진아동의 종성자음 대체오류 비교} 조음방법

종성자음의 조음방법 측면에서 나타난 철자 정확도는 Table 8에 제시된 바와 같다. 전체아동의 조음방법별 철자 정확도는 유음의 정확도가 $97 \%$ 수준으로 가장 높았으며, 그 다음으로는 비음이 $92 \%$ 수준이었으며, 파열음이 $84 \%$ 수준으로 가장 낮았다. 철자부진아동 의 조음방법별 철자 정확도는 $90 \%$ 수준으로 유음의 정확도가 가장 높았고, 그 다음으로 비음이 $82 \%$ 수준이었으며, 파열음은 $65 \%$ 의 정확도로 가장 낮게 나타났다. 일반아동의 조음방법별 철자 정확 도도 유음, 비음, 파열음 순이었으며 모두 $90 \%$ 정확도를 상회하였 다. 철자부진아동과 일반아동의 종성자음 철자정확도는 유음에서 가장차이가 적었으며, 파열음에서 가장 많이 나타났다.

조음방법 측면에서 개별 자소의 철자 정확도를 살펴보면, 철자 부진아동과 일반아동 모두 ‘ㄱ' 자소의 정확도가 ‘ㄷㄱㄱㅘ ‘버사소의 정확도보다 높은 것으로 나타났으며, 철자부진아동의 경우 그 차 이가 더 크게 나타났다. 또한 ‘ㄷㄱㅘ ‘ㅂ' 자소에서는 두 그룹 간의 정 확도의 차이가 두드러졌다. 한편, 비음에서 철자부진아동은 'ㅁ> ᄂ> O' 순으로 정확도가 높은 것으로 나타난 반면, 일반아동은
'ㄴ>ㅁ > O' 순으로 정확도가 높았으며, 'O' 자소에서 두 그룹 간 정확도의 차이가 두드러졌다. 'ㄴ' 자소의 경우 일반아동들은 오류 가 매우 적었으며, 유음 ‘ㄹ' 자소의 경우에는 두 그룹 모두 다른 자 소들에 비해 정확도가 높은 것으로 나타났다.

철자부진의 유무와 종성자음 조음방법의 측면의 대체 오류 양 상에 상관관계가 있는지 검증한 결과(Table 9), 통계적으로 유의미 한 상관관계를 보였다 $\left(\chi^{2}(1, N=397)=23.963, p<.05, \Phi=.25\right)$. 종 성자음을 철자할 때 오류를 범한 경우, 철자부진아동은 타 조음방 법(예: 파열음 ‘ㅂ를 타 조음방법인 비음 ‘ㅁ, ㄴ, ’으로 대체)으로 대체하는 오류(49.6\%)가 동일 조음방법(예: 파열음 '버을 동일한 조 음방법인 파열음 'ㄷ, ᄀᄀ'으로 대체)으로 대체하는 오류(50.4\%)와 비슷하게 분포하였다. 반면, 일반아동은 동일 조음방법으로 대체 하는 오류(74.8\%)가 타 조음방법으로 대체하는 오류(25.2\%)보다 많은 경향성이 있는 것으로 나타났다.

철자부진의 유무와 종성자음 조음방법 대체 유형 간의 유의한 상관관계가 관찰되었으므로 집단별로 대체 오류의 유형 간 차이가 존재하는지 알아보았다. 만-휘트니 $U$ 비모수 통계검증을 실시한 결과(Table 10), 철자부진아동은 타 조음방법 자소로의 대체 빈도 
Table 10. The frequency ratio of substitution types in spelling final consonants by the manner of articulation whithin groups

\begin{tabular}{lccc}
\hline & \multicolumn{2}{c}{ Subsititution types } & \multicolumn{2}{c}{$z$} \\
\cline { 2 - 3 } & Substitution to the different manner of articulation & Substitution the same manner of articulation \\
\hline Students with spelling difficulties & $1.63(1.89)$ & $1.66(1.17)$ & -1.332 \\
Students without spelling difficulties & $.20(.44)$ & $.60(.82)$ & $-5.538^{*}$ \\
\hline
\end{tabular}

Values are presented as mean (SD).

${ }^{*} p<.05$.

Table 11. Spelling accuracy (\%) by the place of articulation of final consonants

\begin{tabular}{|c|c|c|c|c|c|c|c|}
\hline \multirow{2}{*}{$\begin{array}{l}\text { Place of articulation } \\
\text { Bilabial }\end{array}$} & \multirow{2}{*}{$\begin{array}{c}\text { Final consonants } \\
\square \\
\forall\end{array}$} & \multicolumn{2}{|c|}{ Students with spelling difficulties } & \multicolumn{2}{|c|}{ Students without spelling difficulties } & \multicolumn{2}{|c|}{ Total } \\
\hline & & $\begin{array}{l}88.03 \\
56.34\end{array}$ & 72.18 & $\begin{array}{l}96.59 \\
89.76\end{array}$ & 93.17 & $\begin{array}{l}94.38 \\
81.16\end{array}$ & 87.77 \\
\hline Alveolar & $\begin{array}{l}\llcorner \\
ᄃ \\
\text { ट }\end{array}$ & $\begin{array}{l}86.62 \\
59.86 \\
90.85\end{array}$ & 79.11 & $\begin{array}{l}98.29 \\
85.37 \\
99.51\end{array}$ & 94.39 & $\begin{array}{l}95.29 \\
78.8 \\
97.28\end{array}$ & 90.46 \\
\hline Velar & $\begin{array}{l}\text { ᄀ } \\
\circ\end{array}$ & $\begin{array}{l}81.69 \\
71.83\end{array}$ & 76.76 & $\begin{array}{l}96.59 \\
94.15\end{array}$ & 95.37 & $\begin{array}{l}92.75 \\
88.41\end{array}$ & 90.58 \\
\hline
\end{tabular}

Table 12. Substitution errors of final consonants by the place of articulation

\begin{tabular}{|c|c|c|c|c|}
\hline & \multicolumn{2}{|c|}{ Substitution types } & \multirow[b]{2}{*}{ Total substitutions } & \multirow[b]{2}{*}{$x^{2}$} \\
\hline & $\begin{array}{l}\text { Substitution to the different place } \\
\text { of articulation }\end{array}$ & $\begin{array}{l}\text { Substitution to the same place } \\
\text { of articulation }\end{array}$ & & \\
\hline Students with spelling difficulties & $187(79.9)$ & $47(20.1)$ & $234(100)$ & $7.589^{*}$ \\
\hline Students without spelling difficulties & $147(90.2)$ & $16(9.8)$ & $163(100)$ & \\
\hline
\end{tabular}

Values are presented as number (\%).

${ }^{*} p<.05$.

와 동일 조음방법 자소로의 대체 빈도의 차이가 통계적으로 유의 미하지 않았다 $(z=-1.332, p>.05)$. 반면 일반아동은 타 조음방법 자소로의 대체 빈도와 동일 조음방법 자소로의 대체 빈도의 차이 가 통계적으로 유의미한 것으로 나타났다 $(z=-5.538, p<.05)$.

\section{조음위치}

종성자음의 조음위치 측면에서 나타난 철자 정확도는 Table 11 에 제시된 바와 같다. 전체아동의 조음위치별 철자 정확도는 연구 개음과 치조음의 정확도가 $90 \%$ 수준으로 비슷하였으며, 양순음이 $87 \%$ 수준으로 가장 낮았다. 철자부진아동의 조음위치별 철자 정 확도는 79\% 수준으로 치조음의 정확도가 가장 높았고, 그 다음으 로 연구개음 $76 \%$ 수준이었으며, 양순음 $72 \%$ 의 정확도로 가장 낮 게 나타났다. 일반아동은 연구개음, 치조음, 양순음 순으로 정확도 가 높았으며, 모두 $93 \%$ 이상의 정확도를 보였다. 두 그룹 모두 조음 위치상 종성자음군 간의 정확도에는 큰 차이가 없었다. 철자부진 아동과 일반아동 모두 양순음의 철자 정확도가 가장 낮은 것으로 나타났으며, 두 그룹 간 차이도 가장 큰 것으로 나타났다.

조음위치 측면에서 개별 자소의 철자 정확도를 살펴보면, 양순
음에서 철자부진아동과 일반아동 모두 ‘마본은로 정확도가 높은 것으로 나타났으며, 철자부진아동의 경우 두 자소 간 정확도 의 차이가 더 크게 나타났다. 또한 'ㅂ' 자소의 경우 두 집단 간 정확 도의 차이는 두드러졌다. 치조음에서는 두 집단 모두 '리 ᄂ > ᄃ' 순으로 정확도가 높았으며, 'ㄴ, ㄹ' 정확도와 ‘' 정확도의 차이가 큰 것으로 나타났다. 또한 'ㄷ' 자소의 정확도가 두 집단 간 크게 두 드러졌다. 한편, 연구개음에서 철자부진아동과 일반아동 모두 'ㄱ $>$ O' 순으로 정확도가 높았으며, 'O' 자소에서 두 그룹 간 차이가 두드러졌다.

철자부진의 유무와 종성자음의 조음위치 대체오류 양상 간에 상관관계가 있는지 검증한 결과(Table 12), 통계적으로 유의미한 차이를 보였다 $\left(\chi^{2}(1, \mathrm{~N}=397)=7.589, p<.05, \Phi=.01\right)$. 종성자음을 철자할 때 오류를 범한 경우, 철자부진아동은 타 조음위치(예: 양 순음 '버을 타 조음위치인 연구개음 'ㄱ, ㅇ으로 대체)로 대체하는 오류(79.9\%)가 동일 조음위치(예: 양순음 ‘ㅂ'을 동일한 조음위치인 양순음 'ㅁ으로 대체)로 대체하는 오류(20.1\%)보다 많은 경향성이 있는 것으로 나타났다. 일반아동 또한 타 조음위치로 대체하는 오 류(90.2\%)가 동일 조음위치로 대체하는 오류(9.8\%)보다 많은 경향 
Table 13. The frequency ratio of substitution types in spelling final consonants by the place of articulation whithin groups

\begin{tabular}{lccc}
\hline & \multicolumn{3}{c}{ Subsititution types } \\
\cline { 2 - 3 } & Substitution to the different place of articulation & Substitution to the same place of articulation & $z$ \\
\hline Students with spelling difficulties & $2.63(1.91)$ & $.66(.84)$ & $-6.914^{*}$ \\
Students without spelling difficulties & $.72(.89)$ & $.08(.27)$ & $-9.241^{*}$ \\
\hline
\end{tabular}

Values are presented as mean (SD).

${ }^{*} p<.05$.

성이 있는 것으로 나타났다.

철자부진의 유무와 종성자음의 조음위치 대체유형 간의 유의한 상관관계가 발견되었으므로 집단별로 대체 오류의 유형 간 차이가 유의한지 알아보았다. 만-휘트니 $U$ 비모수 통계검증을 실시한 결과 (Table 13), 철자부진아동은 타 조음위치 자소로의 대체 빈도와 동 일 조음위치 자소로의 대체 빈도의 차이가 통계적으로 유의하게 나타났다 $(z=-6.914, p<.05)$. 일반아동 또한 타 조음방법 자소로의 대체 빈도와 동일 조음방법 자소로의 대체 빈도의 차이가 통계적 으로 유의한 것으로 나타났다 $(z=-9.241, p<.05)$

\section{논의 및 결론}

본 연구는 초등학교 1,2 학년 일반아동과 철자부진아동이 보이 는 자음(초성, 종성)철자오류의 차이가 자소특징(조음방법, 조음 위치)에 따라 존재하는지, 아동들이 어떠한 논리를 가지고 철자하 는지에 대해 알아보고자 하였다. 또한 그 논리에는 차이가 있는지 확인함으로써 두 그룹의 철자전략의 차이를 밝히고자 하였다.

먼저 자소가 초성에 위치했을 때와 종성에 위치했을 때 같은 자 소라 하더라도 철자 시 아동이 느끼는 난이도는 다름이 밝혀졌다. 이는 이전의 철자발달연구에서 초성철자유형과 종성철자유형의 발달패턴이 다르며 한글철자유형에 대한 요인분석에서 서로 다른 요인으로 나뉜다는 결과와 일치한다(Yang, 2014). 따라서 뒤따르는 철자분석에서는 한글의 기본자소인 'ㄱ, ᄂ, ᄃ, ㄹ, ㅁ, ㅂ, ㅅ, 0 , 즈르르라음의 위치에 따라 초성과 종성에 위치했을 때로 구분하여 진행하였다.

먼저 초성자음을 철자할 때 철자부진아동과 일반아동의 오류채 택 논리에는 차이가 발견되었다. 철자부진아동의 대체오류들은 조 음방법이 다른 대체오류와 같은 대체오류가 비슷하여, 조음방법에 논리적 기반을 두지 않고 철자를 하는 것을 알 수 있다. 반면, 일반 아동은 다른 조음방법의 자소보다는 같은 조음방법의 자소로 대 체 오류를 범하는 경향성이 유의하게 나타났다. 즉, 일반아동은 자 소가 가지고 있는 조음방법을 인식하고 있으며, 철자를 하는 과정 에서 정확하게 알지 못하는 자소의 경우 조음방법을 기반으로 하
여 대체 오류를 선택한다는 것이다. 이에 반해 조음위치는 일반아 동과 철자부진아동 모두에게 철자논리로 사용되지 않는 것으로 나타났다. 조음특징 및 개별 자소의 초성자음 정확도를 살펴보면, 철자부진아동과 일반아동들이 느끼는 조음방법과 조음위치상의 자음군에 대한 난이도 순서는 다르지 않았다. 그러나 두 집단이 보 이는 철자 정확도는 차이가 났다.

한편, 종성자음을 철자할 때 철자부진아동과 일반아동이 보이 는 오류는 조음방법 측면과 조음위치 측면 모두 관련성이 있는 것 으로 나타났다. 철자부진아동은 대체 오류를 선택할 때 조음방법 에 대한 논리를 활용하지 않고 오류를 범한 반면, 일반아동은 다른 조음방법의 자소보다는 같은 조음방법의 자소로 대체 오류를 범 하는 것으로 나타났다. 조음위치 측면에서는 철자부진아동과 일 반아동 모두 종성자음을 철자할 때 다른 조음위치의 자소로 대체 하는 경우가 동일 조음위치의 자소로 대체하는 경우보다 많았다. 즉, 종성자음을 철자할 때 나타난 오류와 조음위치 측면과 상관관 계는 있었으나, 다른 조음위치로 대체하는 경우가 많은 것으로 보 아 종성을 철자하는 데 자소의 조음위치 논리를 반영하지 않고 있 음을 알 수 있다. 종합하면 자음을 철자 할 때, 일반아동은 조음위 치보다는 조음방법에 기반을 둔 철자전략을 활발하게 사용하는 반면 철자부진아동들은 조음방법과 조음위치 모두 철자전략으로 사용하지 않는 것으로 나타났다. 이러한 결과는 일반아동과 철자 부진아동이 철자를 하는 데 사용하는 철자전략의 차이가 있음을 알 수 있으며, 이는 조음방법과 조음위치 전략 두가지 논리 모두에 기반을 두고 철자를 한다는 이전 추론과는 그 견해를 달리한다 (Read, 1971; Yang, 2009).

철자부진아동들의 조음위치나 조음방법상 철자전략의 오류논 리가 드러나지 않은 이유는 이들의 음소인식 능력이 부족하기 때문 인 것으로 해석해 볼 수 있다. 철자부진아동들은 일반적으로 음소 인식능력이 결핍되어 있다고 밝혀져 있다(Kamhi \& Hinton, 2000). 음소인식은 가장 작은 말소리 단위에 대한 민감성이라고 정의되는 데(Stanovich, 1986), 음소인식능력이 부족하면 단어를 이루고 있 는 음소들을 분석하기 어렵다. 즉, 철자부진아동들이 전반적으로 단어를 이루는 음소의 특징인 조음방법과 조음위치에 대해서도 인 
식하지 못하는 아동들이기 때문에 이와 같이 음소정보와 관련된 논리를 오답채택에 대한 논리로 활용하지 못한 것이라고 추론된다 (Griffiths \& Frith, 2002). 또한 본 연구는 일반아동과 철자부진아 동의 발달순서가 전반적으로 비슷하지만, 종성 ‘ㄷ, 비, ’과 같이 특정 자소의 수행능력에서는 차이가 두드러진다는 것을 밝히기도 하였다.

또 한가지 특기할 만한 발견은 철자발달과 조음발달은 발달상 유사한 점도 있었으나 차이점도 있다는 것이다. 예를 들어, 본 연구 에서 초성자음 ''과 ' $ᄌ$ '은 일반아동과 철자부진 아동 모두 정확 도가 높았던 자소인데 조음발달 상으로 초성 /ㅅ/,/지는 가장 늦게 발달된다고 보고된 바 있다(Kim, 1996). 또한 본 연구에서 종성자 음 'ㄹ' 철자도 일반아동과 철자부진 아동 모두 거의 오류를 보이지 않았으나 조음발달에서는 비교적 늦게 발달하는 음소로 알려져 있 다. 조음과 철자 수행의 이러한 차이는 해당 자음 등이 비교적 조음 방법상 또는 조음위치상의 독립성을 가지고 있기 때문인 것으로 본 다. 자음 'ㅅㅇㅢ 경우 기(aspiration)의 유무 차이만 있는 '써 자음과 동일한 마찰음이지만 조음위치가 상대적으로 독립적인 성문음 ‘’을 제외하고 동일한 조음방법이나 조음위치를 공유하는 자음 이 존재하지 않는다. 또한 자음 'ㅈ'도 기의 유무에 차이가 있는 'ㅊ, 쯔를 제외하고는 조음방법과 조음위치상 독립성을 가진다. 'ㄹ' 자 음 역시 유일한 유음의 자음으로, 이렇게 조음방법상 또는 조음위 치상으로 비교적 독립적인 자음들은 철자하기 쉬운 반면 같은 조 음방법이나 조음위치를 공유하는 자음이 많은 경우는 철자가 어 려운 것으로 결론지을수 있다.

흥미로운 발견에도 본 연구는 몇 가지 제한점을 가지고 있다. 먼 저, 철자부진아동의 철자 오류채택의 논리가 드러나지 못한 이유로 생각되는 음소인식의 결손을 밝히지 못했다는 것이다. 검사의 시공 간적 제약으로 인해 개별검사로 이루어지는 음소인식검사를 실시 하기 못했기 때문에 이들 아동의 음소인식 능력을 철자부진아동들 의 오류논리의 원인으로 설명하는 데는 한계가 있었다. 철자부진 아동의 오류논리의 원인을 파악하기 위해 음소인식 능력을 살펴보 는 추후 연구가 진행될 필요성이 있으며, 더불어 음소인식의 발달 과 철자발달을 비교하여 살펴본다면 흥미로운 연구주제가 될 것이 라고 생각한다. 두 번째, 본 연구의 결과 드러난 자음의 철자발달의 순서는 Kim (1996)이 보고한 자음의 조음발달 순서와 동일한 분석 방법을 사용했기 때문에 비교가 가능했다는 점은 긍정적으로 볼 수 있다. 그러나 자음의 철자발달 순서를 기술통계로만 보고하였 을 뿐 통계적으로 그 순서를 증명할 수 없었던 점은 본 연구의 제한 점이다. 따라서 향후 연구에서는 발달순서를 통계적으로 검증할 수 있는 방법인 order statistics 등의 방법을 사용하여 발달순서에
대해 통계적 근거를 제시하는 것이 필요하다.

또한 본 연구는 음운학적 측면에서 대체오류를 분석하였기 때문 에 형태적 측면이나 시각적인 측면에서 나타날 수 있는 영향에 대 해서는 알아보지 못하였다. 아동이 대체오류를 선택할 때 시각적 으로 비슷한 자소로 대체오류를 범하거나, 혹은 목표 자소의 앞, 뒤 에 있는 자소의 영향을 받아 대체오류를 선택을 하기도 하는 등 다 른 측면에서의 철자전략의 영향이 존재할 수 있다. 하지만 본 연구 에서는 조음요소가 자음의 철자능력에 전략으로 사용되는지의 여 부가 연구문제였으므로 이를 고려하지 않았다. 따라서 앞으로 음 운학적 측면 외에 철자오류와 관련하여 형태적, 시각적 측면 등 다 양한 시각에서의 철자전략 연구가 필요하다고 생각된다.

마지막으로 일반아동도 철자를 하는 데 조음위치의 논리를 사 용하지 않는다는 결과는 이유를 설명하기 어려웠으나 흥미로운 결 과이다. 한글 창제 시에 조음위치를 본 뜬 모양으로 자소를 만들었 을 만큼 조음위치에 대한 단서를 제공하기 위해 노력한 자모를 가 지고 있음에도 불구하고, 아동들이 이를 철자논리로 채택하지 않 는 이유를 밝힐 필요가 있다. 그 이유는 여러 가지가 될 수 있는데, 철자 시 조음방법이 상대적으로 조음위치보다 더 중요한 단서였기 때문으로 추측해볼 수 있다. 그러나 본 연구에서는 이러한 추측이 맞는지, 또 왜 조음방법이 조음위치보다 더 중요한 정보인지 밝힐 수 없었다. 일반아동들이 조음위치에 대한 논리를 철자전략으로 쓰지 않는 이유에 대해서 향후 연구에서 응용심리언어적인 견지에 서 다루어볼 가치가 있다고 생각된다.

본 연구는 철자부진아동과 일반아동이 철자발달상에 나타나는 특징적인 차이를 조음방법과 조음위치 측면에서 아동의 논리를 파 악하여 철자전략을 밝혔다는 점에서 의의가 있다. 일반아동과 철 자부진아동의 철자전략에 차이가 있다는 점은 이들 아동들에게 철자교수를 제공할 때 차별화된 접근법이 필요하다는 것을 시사한 다. 본 연구의 결과를 바탕으로 교육 현장에서 철자부진아동과 일 반아동의 특징을 파악하고 이들의 철자전략에 맞춘 교수를 계획 하는 데 도움이 될 것으로 기대한다.

\section{REFERENCES}

Afflerbach, P., Pearson, P. D., \& Paris, S. G. (2008). Clarifying differences between reading skills and reading strategies. The Reading Teacher, 61, 364373.

Anthony, J. L., \& Francis, D. J. (2005). Development of phonological awareness. Current Directions in Psychological Science, 14, 255-259.

Beers, J. W., Beers, C. S., \& Grant, K. (1977). The logic behind children's spell- 
ing. The Elementary School Journal, 77, 238-242.

Ehri, L. C. (2000). Learning to read and learning to spell: two sides of a coin. Topics in Language Disorders, 20, 19-36.

Griffiths, S., \& Frith, U. (2002). Evidence for an articulatory awareness deficit in adult dyslexics. Dyslexia, 8, 14-21.

Henderson, E. H. (1990). Teaching spelling (2nd ed.). Boston, MA: Houghton Mifflin Company.

Kamhi, A. G., \& Hinton, L. N. (2000). Explaining individual differences in spelling ability. Topics in Language Disorders, 20, 37-49.

Kim, A. H., Choi, H. N., \& Kim, J. H. (2010). Spelling skills of students with or without spelling difficulties in Korea: focusing on spelling accuracy and error patterns. Journal of Special Education, 45, 203-223.

Kim, K. H. (2003). Educational vocabulary by level. Seoul, Korea: Pagijong Press.

Kim, Y. S. (2010). Componential skills in early spelling development in Korean. Scientific Studies of Reading, 14, 137-158.

Kim, Y. T. (1996). The percentage of consonants correct of preschool children for picture articulation test. Korean Journal of Communication Disorders, 1 , $7-33$.

Lee, I. S. (2011). An introduction to Korean linguistics. Seoul, Korea: Hakyonsa Press.

Lennox, C., \& Siegel, L. S. (1996). The development of phonological rules and visual strategies in average and poor spellers. Journal of Experimental Child Psychology, 62, 60-83.

National Reading Panel. (2000). Teaching children to read: an evidence-based assessment of the scientific research literature on reading and its implications for reading instruction. Washington, DC: National Institute of Child Health and Human Development, National Institutes of Health.
Read, C. (1971). Pre-school children's knowledge of English phonology. Harvard Educational Review, 41, 1-34

Rvachew, S., Ohberg, A., Grawburg, M., \& Heyding, J. (2003). Phonological awareness and phonemic perception in 4-year-old children with delayed expressive phonology skills. American Journal of Speech-Language Pathology, 12, 463-471.

Shin, S. W., \& Cho, S. C. (2001). Comparative study upon the characteristics of writing between the patients with writing disabilities and normal elementary school students. Journal of the Korean Academy of Child and Adolescent Psychiatry, 12, 51-70.

Stanovich, K. E. (1986). Matthew effects in reading: some consequences of individual differences in the acquisition of literacy. Reading Research Quarterly, 21, 360-407.

Thomas, E., \& Sénéchal, M. (2004). Long-term association between articulation quality and phoneme sensitivity: a study from age 3 to age 8 . Applied Psycholinguistics, 25, 513-541.

Treiman, R. (1984). On the status of final consonant clusters in English syllables. Journal of Verbal Learning and Verbal Behavior, 23, 343-356.

Treiman, R., Broderick, V., Tincoff, R., \& Rodriguez, K. (1998). Children's phonological awareness: confusions between phonemes that differ only in voicing. Journal of Experimental Child Psychology, 68, 3-21.

Weiner, S. (1994). Four first graders' descriptions of how they spell. The Elementary School Journal, 94, 315-330.

Yang, M. (2009). Spelling development of Kindergarten students: a one year longitudinal study. Korean Journal of Communication Disorders, 14, 14-33.

Yang, M. (2014). Children's spelling of phonological and morphological features in primary grades. Communication Sciences and Disorders, 19, 120131. 
Appendix 1. 검사단어와 목표유형

\begin{tabular}{|c|c|c|c|c|c|c|c|c|c|c|c|c|c|c|c|}
\hline \multirow{2}{*}{ 단어 } & \multicolumn{8}{|c|}{ 기본초성 } & \multicolumn{7}{|c|}{ 기본종성 } \\
\hline & $\neg$ & ᄂ & ᄃ & ᄅ & 口 & $\forall$ & 人 & x & /ᄀ/ & ᄂ & /ᄃ/ & ᄅ & $\square$ & /ㅂ/ & o \\
\hline 굴복 & \urcorner & & & & & $\forall$ & & & & & & ᄅ & & & \\
\hline 단독 & & & ᄃ & & & & & & /ᄀ/ & ᄂ & & & & & \\
\hline 간섭 & \urcorner & & & & & & 人 & & & ᄂ & & & & /ㅂ/ & \\
\hline 수립 & & & & ᄅ & & & & & & & & & & & \\
\hline 능선 & & ᄂ & & & & & 人 & & & & & & & & \\
\hline 낭독 & & ᄂ & ᄃ & & & & & & & & & & & & ○ \\
\hline 조립 & & & & ᄅ & & & & & & & & & & $/ \forall /$ & \\
\hline 장악 & & & & & & & & x & /ᄀ/ & & & & & & ० \\
\hline 맡는 & & & & & 口 & & & & & & & & & & \\
\hline 묶기 & & & & & $\square$ & & & & & & & & & & \\
\hline 밝고 & & & & & & $\forall$ & & & & & & & & & \\
\hline 남짓 & & & & & & & & ス & & & /ᄃ/ & & ㅁ & & \\
\hline 낮잠 & & & & & & & & & & & /ᄃ/ & & $\square$ & & \\
\hline 찰싹 & & & & & & & & & & & & ᄅ & & & \\
\hline
\end{tabular}




\section{국문초록}

\section{일반아동과 철자부진아동의 철자전략 비교: 음소의 조음정보를 중심으로}

김보배 · 양민화

국민대학교 교육학과

배경 및 목적: 철자오류는 문자체계를 인식하는 언어학적인 논리를 보여주기 때문에 아동이 사용하는 철자전략을 확인할 수 있다. 본 연구에서는 일반아동과 철자부진아동의 자음 철자오류에 질적 차이가 자음의 조음방법과 조음위치에 따라 존재하는지, 철자오류의 논리에는 차이가 있는지 살펴봄으로써 두 그룹의 철자전략의 차이를 밝히고자 하였다. 방법: 초등학교 1,2 학년 일반아동과 철자부진 아동 276 명을 대상으로 철자검사를 실시하였다. 초성자음과 종성자음을 철자할 때 조음방법과 조음위치 측면에서 대체오류의 양상과 철자부진 간의 상관관계가 있는지 알아보기 위해 카이제곱검정을 실시하였다. 또한 만-휘트니 $U$ 비모수 통계검증을 통해 집단 내에서 대체오류의 유형에 차이가 있는지 알아보았다. 결과: 첫째, 조음방법 측면의 철자오류양상과 철자부진과의 상관관계는 초성자음과 종 성자음에서 모두 유의한 반면, 조음위치 측면의 철자오류양상과 철자부진과의 상관관계는 종성자음에만 있었다. 둘째, 조음방법에서 일반아동은 초성과 종성자음 모두 다른 조음방법보다는 동일한 조음방법으로 대체한 경우가 유의하게 많았으나, 철자부진아동은 차 이가 없었다. 조음위치 에서는 일반아동과 철자부진아동 모두 종성자음 철자 시 동일한 조음위치보다는 다른 조음위치로 대체한 경우 가 많았다. 논의 및 결론: 일반아동들은 목표자소의 조음방법에 대한 철자전략을 활발하게 활용하고 있는 데 비하여 철자부진아동들 은 조음방법전략을 활용하지 않는 것으로 나타났다. 목표자소의 조음위치전략은 일반아동과 철자부진아동 모두 사용하지 않았다. 이 러한 결과는 일반아동과 철자부진아동의 철자전략에 차이가 있으며, 철자교수 시 차별화된 접근법이 필요함을 시사한다.

핵심어: 철자전략, 철자부진, 조음방법, 조음위치

\section{참고문헌}

김광해(2003). 등급별 국어교육용 어휘. 서울: 박이정.

김애화, 최한나, 김주현(2010). 초등학교 철자부진학생과 일반학생의 철자 특성 비교 연구. 특수교육학연구, 45, 203-223.

김영태(1996). 그림자음검사를 이용한 취학전 아동의 자음정확도 연구. 말-언어장애연구, 1, 7-33.

신성웅, 조수철(2001). 쓰기 장애 환자와 정상 초등학교 학생의 쓰기 특성 비교. 소아.청소년정신의학, 12, 51-70.

양민화(2009). 유치원 아동의 철자발달 단기종단연구. 언어청각장애연구, 14, 14-33.

양민화(2014). 음운론적 유형과 형태론적 유형의 초기 철자발달. 언어청각장애연구, 19, 120-131.

이익섭(2011). 국어학 개설. 서울: 학연사. 